\title{
O tempo da notícia: cidade, ditadura e redemocratização nas páginas de 0 Estado (Florianópolis, SC, 1964-1985)
}

Reinaldo Lindolfo Lohn*

Resumo: Este artigo aborda as relações entre as narrativas elaboradas no jornal O Estado, de Florianópolis (SC), as mudanças socioculturais ocorridas na cidade e os processos políticos ligados à ditadura militar e aos primeiros anos da recente redemocratização do Brasil. O discurso jornalístico mostra-se como um organizador do social, o que inclui a definição sobre o que deve ser lembrado ou esquecido. Narrativas elaboradas nas páginas do jornal constituíram-se em suportes para memórias e para a construção da consciência histórica acerca do tempo presente vivenciado durante a transição entre a ditadura e a democracia. Palavras-chave: Jornal. Narrativa. Tempo presente. Ditadura. Democratização.

\section{O jornal e o tempo}

No início de 1968, uma matéria publicada no jornal O Estado tratou das mudanças que ocorriam em Florianópolis, capital de Santa Catarina, e evidenciou a chegada de um novo ritmo social. Com o título "O tempo passou na janela", o texto afirmou que "as velhas construções que, resistindo ao tempo, se espalham por vários pontos da cidade, trazem a marca de uma época já passada." Fotos mostravam idosos em sacadas e janelas de casas antigas e o texto

\footnotetext{
* Professor do Departamento e do Programa de Pós-Graduação em História da Universidade do Estado de Santa Catarina (UDESC). Doutor em História (2002) pela Universidade Federal do Rio Grande do Sul (UFRGS). E-mail: reilohn@gmail.com
} 
discorria sobre vivências passadas, das quais restara "apenas as casas, as igrejas, as janelas". Embora "a nenhuma delas o tempo perdoou", estavam a "manter a dignidade de outras épocas" e de um "passado distante e cada dia mais fugidio" e recebiam "as últimas aragens do vento sul", enquanto "lá fora, além da janela, o tempo passa” (07/01/1968, Suplemento, p. 1). A idéia de experimentar uma nova temporalidade foi registrada na imprensa e passou a fazer parte das percepções e lembranças dos contemporâneos. O jornal $O$ Estado registrou, à sua maneira, o que entendeu ser a chegada de um novo tempo e acentuou as transformações visíveis na paisagem e nas sociabilidades. No período que compreendeu a ditadura civil-militar imposta em 1964 e a recente redemocratização, as experiências e contingências políticas e socioculturais estiveram em grande medida articuladas às alterações observadas nas cidades, as quais compreenderam processos sociais simultâneos e justapostos, compartilhados através de mecanismos próprios da cultura de massas.

Esta é uma característica a ser acentuada ao dedicar-se a escrever uma História do tempo presente: compreender que os acontecimentos e processos que recebem o estatuto de históricos são constantemente mobilizados através de operações que se passam nos meios de comunicação de massa, os quais funcionam como veículos de memórias. A partir da década de 1980, Florianópolis tornou-se nacionalmente conhecida como pólo turístico. Localizada na Ilha de Santa Catarina e na península continental adjacente, o poder público e o setor empresarial aproveitaram os atrativos naturais, principalmente dezenas de praias e balneários, para a promoção de empreendimentos imobiliários e de lazer. Seu desenvolvimento urbano, no período compreende a instauração do regime autoritário em 1964 e o começo da década de 1980, demonstra que o repertório de práticas de gestão das cidades implementado ao longo da ditadura militar e os desdobramentos posteriores não se restringiram aos grandes centros metropolitanos. Processaram-se ainda tramas entre Estado e investimentos privados, baseadas nos desejos despertados pelos processos de modernização da segunda metade do século XX no Brasil.

Imagens e fatos elaborados nas páginas dos jornais constituem suportes para memórias compartilhadas por uma grande 
coletividade. Segundo Jacques Le Goff, a inteligibilidade das tessituras que dizem respeito à construção de eventos e fatos alçados ao estatuto de "acontecimentos históricos" envolve a intervenção dos veículos de comunicação de massa (1994, p. 142-143). A memória social passa a ser composta pelo "discurso da informação", que apresenta a sucessão de acontecimentos narrados na imprensa como parte de uma história vivida, imediatamente memorizada e escrita, a formar conjuntos de crenças e símbolos, regras e práticas, os quais são combinados para significar o real e estabelecer normas sociais, de modo a homogeneizar os imaginários sociais. Jürgen Habermas (1984, p. 42-46) considera a imprensa uma instituição fundamental para a compreensão do imaginário político moderno, na conformação de uma opinião pública pretensamente em posição de autonomia diante do Estado, em defesa dos diversos interesses particulares que formam a sociedade civil, liberal e burguesa. $\mathrm{O}$ discurso jornalístico apresenta-se nas sociedades contemporâneas, não apenas como emissor de informações como uma das mais destacadas instâncias organizadoras do social, o que incluiu a definição sobre o que deve ser lembrado ou esquecido.

Naquela década, O Estado firmou-se definitivamente como o mais importante jornal da cidade e uma das peças de um jogo de interesses político-empresariais em Santa Catarina. Fundado em 1915, a empresa jornalística passara por diferentes proprietários até ser adquirida por Aderbal Ramos da Silva (1911-1985), em 1946, liderança estadual do Partido Social Democrático e dirigente de um dos maiores grupos empresariais de Santa Catarina (PEREIRA, 1992, p. 118). Com o golpe civil-militar de 1964 e a posterior fusão dos partidos conservadores na Aliança Renovadora Nacional (ARENA), seus concorrentes tenderam a desaparecer ou a reduzir seus círculos de influência. Até então, não havia órgão de imprensa na cidade que não fosse diretamente vinculado a partidos. Durante a vigência da ditadura civil-militar, o panorama do mercado jornalístico brasileiro experimentou significativas mudanças. Os meios de comunicação de massa atravessaram um momento de renovação em suas estruturas administrativas, com mecanismos de gestão empresariais que tenderam a promover uma concentração no mercado em favor dos mais competitivos. Estas alterações mostraram-se também 
em outros aspectos, como a diagramação e a apresentação gráfica. As inovações tecnológicas e as exigências profissionais demandaram investimentos de grande porte e assim, ocorreu "[...] um processo mais geral de reconfiguração do mercado de imprensa, com consequências profundas no campo jornalístico, em termos tanto econômicos como técnico-profissionais" (RIBEIRO, 2006, p. 426-435).

O Anuário Estatístico do Brasil, do Instituto Brasileiro de Geografia e Estatística, registrou a existência, em 1962, de dois jornais diários matutinos em Florianópolis, $O$ Estado e seu tradicional concorrente $A$ Gazeta, com uma tiragem média somada de 11.000 exemplares, o que era significativo dado que a tiragem média estadual de jornais não passava de 27.000 exemplares (IBGE, 2003). Não havia um único jornal que cobrisse todo o Estado, o que inclusive abriu possibilidades para que o Correio do Povo, de Porto Alegre, viesse a explorar o mercado do interior do Estado, com sucursais nas principais cidades. $\mathrm{Na}$ década seguinte, o processo de modernização do mercado de bens culturais no Brasil criaria condições para o crescimento das empresas jornalísticas de Santa Catarina, numa época em que os controles exercidos pelo regime autoritário sobre a imprensa estavam focados no noticiário nacional, o que garantia alguma margem de atuação para a imprensa regional (PEREIRA, 1992, p. 68-75).

Em 1974, a tiragem total dos jornais brasileiros, só nas capitais estaduais, atingiu um número próximo a 1 bilhão de exemplares. Neste mesmo ano, circulavam 3 jornais diários matutinos em Florianópolis com uma tiragem total de de 6.238.000 exemplares, o que indica que a tiragem média havia aumentado para cerca de 20.000 exemplares, certamente com participação majoritária de $O$ Estado, pois a esta altura seus concorrentes locais estavam praticamente inviabilizados pela intensificação da concorrência. Em todo o Estado de Santa Catarina, naquele ano, a tiragem total dos jornais fora de mais de 14 milhões e atingiria mais de 21 milhões de exemplares em 1981 (IBGE, 2003). Neste momento de expansão do mercado jornalístico regional surgiu, em 1971, o Jornal de Santa Catarina, sediado em Blumenau, mas com forte presença na capital, que trouxe uma série de inovações editoriais, favorecidas por fazer parte de um grupo empresarial com atuação consolidada na mídia 
eletrônica, através da TV Coligadas (BALDESSAR; CHRISTOFOLET'TI, 2005, p. 59-60). Como resposta, uma série de mudanças tecnológicas, de perfil profissional e atuação no mercado logo seriam incorporadas por seus principais concorrentes estaduais, primeiro em $O$ Estado e, um pouco mais tarde, em $A$ Notícia, de Joinville.

$O$ jornal $O$ Estado foi um espectador, um participante e um beneficiário da dinamização da economia e da urbanização ocorridas durante o período autoritário. Seus dirigentes promoveram investimentos que modernizaram sua estrutura e seu desenvolvimento editorial, com a chegada de jornalistas de outros centros do país e de jovens profissionais que atuavam na cidade. A partir de 1972, a impressão off-set e o aumento do número de páginas aproximaram o jornal do modelo predominante nas grandes capitais do país, ao mesmo tempo em que a cidade passava por importante transformação urbana. Àquela altura, $O$ Estado apresentou características de um jornalismo moderno e com diversidade informativa, o que destoava de seu passado intrinsecamente vinculado à política partidária (BALDESSAR; CHRISTOFOLETTI, 2005, p. 73-77).

Mas, de certa forma, na década de 1980, O Estado foi vítima do próprio crescimento do mercado de mídia de Santa Catarina. Sofreu, a partir de então, a concorrência do grupo RBS (Rede Brasil Sul), que dominava a mídia eletrônica no Estado desde 1979 e lançaria o jornal Diário Catarinense em 1986. Este mesmo grupo empresarial adquiriu, alguns anos depois, tanto o Jornal de Santa Catarina quanto $A$ Notícia e, assim, controlou quase completamente o mercado de informação catarinense. Com enormes dificuldades financeiras e incapaz de sustentar uma posição de mercado ante à concorrência, o jornal então conhecido como "O mais antigo" teve sua circulação comprometida, até desaparecer por completo, quase anonimamente, quando não passava de um tablóide semanal com poucas páginas, em 2008.

\section{O tempo por escrito}

Em 1964, ainda com vigor empresarial, jornalístico e, principalmente, político, $O$ Estado esforçara-se em apresentar uma cidade em que, apesar da deflagração do golpe civil-militar, tudo corria "em 
O tempo da notícia: cidade, ditadura e redemocratização...

perfeita paz", com "todos os estabelecimentos escolares funcionando normalmente", comércio e indústria "trabalhando sem impedimentos" e o "povo aguardando com calma, o desenrolar dos acontecimentos" (02/04/1964, p. 1). Até final da década, imagens concorrentes e paralelas foram constantemente evocadas pelo jornal. Foi comum a primeira página ser ocupada por fotografias que registravam o que seriam os remanescentes de outro tempo. Edifícios públicos, casarios e práticas sociais, como o uso de carroças, atos cerimoniais ou a venda de louças de barro foram temas comuns. Sob o título "Os dias contados", a foto de um casarão abandonado com janelas cerradas foi acompanhada da seguinte legenda "de costas para a baía, as velhas casas de Florianópolis tendem a desaparecer com o surto progressista e imobiliário que toma conta da cidade. Hoje, a antiga Desterro é um amálgama de revolução e tradição" (09/05/1967, p. 1). O antigo trapiche municipal, conhecido como Miramar, despedia-se porque não despertava mais "o antigo gosto que tinham os vovôs e as vovós" de frequentar suas instalações (10/03/1968, p. 8). Outra fotografia registrou a leitura de jornal por um senhor, sob a figueira da Praça XV de Novembro, com o título "Costume antigo" e o texto: "O velho hábito da leitura dos jornais nos bancos da figueira ainda permanece e por certo não desaparecerá tão cedo" (19/07/1968, p. 1).

Por outro lado, as mensagens publicitárias das empresas incorporadoras e construtoras, em análogo diapasão discursivo, celebravam a nova temporalidade. Os anúncios buscavam compartilhar o espanto e o entusiasmo com a rapidez das mudanças. A frase "há 8 meses atrás, aqui não existia nada” encabeçou um texto publicitário de mais um edifício erguido na cidade. As referências à História e à passagem do tempo são nítidas: "Era uma antiga residência da velha Desterro... De repente, no último verão, chegaram as máquinas e as escavadeiras; bate estacas e homens com ferramentas" $(13 / 10 / 1968$, p. 2). Há aí uma pequena narrativa histórica que junta alteração de ritmos, velocidade e referências socioculturais que se pretendem compartilhadas pelo emissor da mensagem publicitária e seu público. É uma espécie de operação de escrita histórica, sem ser historiográfica, evidentemente. Sabe-se que a alavancagem da construção civil foi um dos pilares da política econômica levada a 
cabo pelos governos militares (PRADO; EARP, 2003, p. 225). Essa dinâmica transformou não apenas grandes cidades, mas contribuiu para constituir um importante segmento de cidades médias, como é o caso de Florianópolis.

A narrativa jornalística aponta para indícios de "experiências" e "expectativas" de grupos sociais de Florianópolis, relativos aos usos sociais de espaços e lugares numa cidade em mudança. Um tempo histórico em mutação, entendido, conforme Reinhart Koselleck, como o entrelaçamento de passado e futuro (2006, p. 305327), manifestou-se na trama de uma narrativa compartilhada socialmente através de diversos meios, dos quais pode-se encontrar indícios nos jornais, e fez-se presente nas vivências cotidianas da população, a orientar tanto as imagens de futuro quanto as avaliações retroativas acerca das trajetórias individuais e coletivas. As expectativas assentadas nas promessas de crescimento urbano e nas políticas econômicas dos governos da ditadura foram articuladas às experiências sociais reconhecidas, numa aglomeração de temporalidades orquestrada através de um conjunto de narrativas que dotava de sentido o conjunto disperso de elementos encontrados no dia-a-dia: os novos edifícios, o ritmo de vida acelerado, a abertura de avenidas, a chegada de imigrantes e a mobilidade social ascendente das camadas médias.

Na acepção filosófica de Jörn Rüsen, o conhecimento histórico apresenta-se como "um modo particular de um processo genérico e elementar do pensamento humano". Ao desenvolver uma consciência sobre o tempo e ao agir intencionalmente, o homem interpreta o mundo. Esta operação ocorre "sempre de modo todo especial quando os homens têm de dar conta das mudanças temporais de si e do mundo mediante seu agir e sofrer" e, assim, é formado "um quadro interpretativo" das experiências em mudança no tempo (2001, p. 56-58). Pode-se intuir que no tempo presente houve uma mescla mais nítida do tempo como experiência e do tempo como intenção. Alguns contemporâneos daqueles processos socioculturais em Florianópolis, observadores em posição privilegiada, deixaram registrado na imprensa a posse de uma consciência histórica pragmática e uma determinada orientação temporal, informada por referências sobre a alteração de ritmos sociais, sobre o que se passava. Numa crônica a respeito do que mudava na cidade, um intérprete daqueles tempos narrou que "o fonfonar do dia a dia, a massa que se 
despeja das repartições públicas e das casas de comércio em busca dos coletivos, em todas as direções, representam o pacto do presente com um futuro cada vez mais barulhento" (O Estado, 07/01/1968, p. 2).

Referências às mudanças na temporalidade vivida, através da narrativa seqüencial, foram empregadas em outro anúncio que trazia uma pequena tira de quadrinhos na qual um personagem, em 1960, teria pensado: "investir em Florianópolis? Iihh! Nem me fale nisso!". Passados alguns anos e, com alterações de pontos de vista, em 1964, o mesmo personagem afirmava: "imóveis na Capital? Sim, creio que já é possível!”. Para confirmar a conclusão, um texto informava que, em 1967, muitas pessoas de outras cidades haviam adquirido imóveis na cidade, por diversas razões: "há gente que busca as praias; outros a universidade. E há os que querem simplesmente aplicar em imóveis, aproveitando o rápido desenvolvimento da Capital" (O Estado, 16/06/1967, p. 5).

Os jornais registraram os processos de modernização urbana e permitem o acesso à construção de uma memória histórica, no momento de sua produção. Esta constatação dá-se no conjunto de discussões referentes às relações entre História e Memória, que permitiram "aos historiadores repensar as relações entre passado e presente e definir para a história do tempo presente o estudo dos usos do passado", como aponta Marieta de Moraes Ferreira (2001, p. 321). Neste campo de disputas políticas, os meios de comunicação de massa passaram a ter importância decisiva, ao narrar e ordenar de certa maneira o conjunto de representações que a sociedade fez de si mesma, do seu passado e projetou para seu futuro coletivo. Para Serge Bernstein (1998, p. 352-353), “a cultura política, como a própria cultura, se inscreve no quadro das normas e dos valores que determinam a representação que uma sociedade faz de si mesma, do seu passado, do seu futuro".

Os jornais apresentam-se como fontes indispensáveis para compreender um passado presente, não como algo estável e congelado, mas também como suportes de uma memória intencionalmente produzida, ao instaurar sentidos e legitimar determinados processos políticos (DECCA, 1992, p. 133). Neste caso, os jornais são mediadores de lembranças, posto que também "é pelo discurso de terceiros que os sujeitos são informados sobre o resto dos fatos contemporâneos a eles", através de construções baseadas 
em fontes "crescentemente midiáticas" (SARLO, 2007, p. 90-92) e que influenciaram as percepções e lembranças de um período de tempo recente, com impactos tanto nas trajetórias individuais quanto em experiências coletivas. $\mathrm{O}$ discurso jornalístico ocupou "o papel institucional de produzir sentidos passíveis de inscrição na memória social", daí a necessidade de examinar "de que modo vem a instituir-se e a produzir os efeitos de verdade e consenso que muitas vezes acabam por orientar nossas ações e nosso pensar" (RIBEIRO; FERREIRA, 2007, p. 58).

No início da década de 1970, a população de Florianópolis girava em torno de 120 mil habitantes. Um anúncio publicitário em $O$ Estado mostrava uma charge na qual um personagem parecia sonhar acordado e, em tom de desejo, pensava: "morar no centro... Ah! Morar no centro" (17/07/1968, p. 1). A construção de edifícios de apartamentos em escala crescente, modificou em profundidade a fisionomia e a estrutura urbana. Áreas tradicionalmente ocupadas por residências requintadas das camadas mais altas das cidades foram propiciadas à moradia das novas camadas médias urbanas, através do processo de verticalização. Os anúncios publicitários citavam, por exemplo, a possibilidade de morar em "uma rua aristocrática... um local arborizado, onde você mora perfeito!” (08/12/1967, p. 5).

O desejo por adquirir apartamentos possibilitou políticas de crédito imobiliário: funcionários públicos em cargos de chefia e profissionais liberais afirmaram-se como consumidores de apartamentos de três dormitórios (PEREIRA, s/d, p. 88). Entre as práticas culturais identificadoras das classes médias urbanas, o jornal registrou, em 1970, que "o florianopolitano já começou a manifestar uma acentuada preferência pela fixação de residência em condomínios" e "os compradores de imóveis, notadamente de apartamentos situam-se na faixa dos 'mais bem atendidos', em termos de opções e de qualidade". Com satisfação constatava-se que "morar em apartamentos já não é privilégio de uma minoria de alta renda" que exigia "projetos nobres, requintados, luxuosos e de extremo bom gosto", pois "toda a classe média passa a fazer as mesmas exigências” (O Estado, 08/07/1970, p. 5).

Os governos da ditadura intensificaram o processo de montagem de uma máquina estatal complexa, com mecanismos de gestão que exigiram a constituição de segmentos burocráticos, compostos 
por técnicos e especialistas. O planejamento governamental e as novas oportunidades de investimento na cidade criaram um cenário novo em Florianópolis: "o admirável impulso que a Capital tem recebido nos últimos anos e o seu benfazejo despertar para as potencialidades de que dispõe, a fim de ingressar definitivamente nas sendas do progresso que se traçou, dão hoje uma perspectiva bastante animadora em relação ao futuro de toda a área a que se acha integrada" (O Estado, 13/08/1968, p. 4). Novos mecanismos de intervenção estatal na economia, através de empresas públicas recém criadas, ao oferecer oportunidades de emprego para uma burocracia de nível médio e superior, criaram condições para que novas camadas médias fossem incorporadas à cidade (LOHN, 2011).

O Plano Nacional de Habitação, cuja execução seria financiada pelo Banco Nacional de Habitação (BNH), proporcionou linhas de crédito para construtores e compradores de moradias e facilitou a implantação de projetos de infraestrutura urbana. Em O Estado, campanhas publicitárias mostravam uma nova vida urbana ao alcance das classes médias. Seria possível "pensar seriamente na mudança" para um novo conjunto de edifícios confortáveis, com "áreas talentosamente planejadas" e apartamentos financiados "via Crédito Imobiliário, através do plano de Equivalência Salarial" (01/07/1972, p. 12). Estas referências compuseram discursos que estiveram na base da propaganda oficial dos governos militares. Carlos Fico (1997, p. 137) denomina "reinvenção do otimismo" a esta elaboração que buscava associar a confiança no "destino de grandeza do país" às certezas em relação ao porvir de cada brasileiro.

Enquanto o crescimento da construção civil na cidade mantinha níveis acelerados, a dificuldade para conseguir moradia na cidade veio à tona nas páginas dos jornais de uma maneira inusitada. Acompanhando a mobilização nacional promovida pela União Nacional dos Estudantes (UNE), em Florianópolis o movimento estudantil ocupou as ruas protestos contra a política educacional e a ausência de moradia estudantil. "Um mar de protestos" foi uma manchete de meados de 1968: "um mar de faixas e cartazes criticando a política educacional do governo e a reitoria da UFSC [Universidade Federal de Santa Catarina] levou às ruas o protesto dos estudantes universitários" (O Estado, 16/05/1968, p. 1). As 
fotografias publicadas em $O$ Estado mostraram faixas como dizeres como "menos armas para calar, mais verbas para educar" ou "um jovem que deixa de estudar hoje é um técnico que faltará ao Brasil amanhã". O assassinato do estudante Edson Luís de Lima Souto, no Rio de Janeiro, provocou protesto em Florianópolis e o Diretório Central de Estudantes manifestou-se contra "o arrocho do poder militarista que se instalou na direção do país” (31/03/1968, p. 1). Em seguida, foi deflagrada uma greve estudantil contra a retenção de verbas por parte do Ministério da Educação e a ausência de políticas de moradia estudantil. Foi anunciada uma ação popular para questionar "o contrato Daux-Reitoria". Os manifestantes denunciavam "os termos do contrato de locação das Casas de Estudantes" que, mantidas com recursos da Reitoria, geravam benefícios para uma empresa do setor imobiliário da cidade (04/06/1968, p. 4).

Com o recrudescimento da ditadura, após a instauração do Ato Institucional Número 5 (AI-5), as referências a formas de ocupação diversificada dos espaços públicos na cidade praticamente desapareceram do noticiário. Até então haviam sido comuns informações sobre manifestações diversas. Enquanto as ruas eram tomadas pelos estudantes em protestos ou em "trotes" aos calouros, o jornal $O$ Estado mostrava personagens conhecidos pela população. Em certa ocasião, o tema foi uma mulher conhecida como "Marta Rocha" que freqüentava o centro e fora "incorporada quase ao nosso folclore" (04/05/1967, p. 1). Os clubes de remo, numa época em que a linha de mar fazia fronteira com as ruas centrais mais importantes, antes dos grandes aterramentos da década seguinte, também celebravam vitórias em manifestações públicas. No dia 14 de Novembro de 1967, o jornal registrou que "na euforia da vitória, remadores e sócios do Riachuelo percorreram as ruas centrais da cidade comemorando ruidosamente a conquista do tricampeonato" (p. 1).

Outro tema do jornal foi o Mercado Público, considerado o "principal armazém da cidade", no qual "as donas de casa já se acostumaram ao ritual de todas as manhãs, quando vão às compras, encontram-se com as amigas e discutem as cotações da 'bolsa' dos gêneros de todas as necessidades". Contudo, ao cair da noite, chegavam também as "sombras" de seu "submundo", composto por personagens que pareciam "extraídos de alguma crônica da Idade 
Média": carregadores e miseráveis indigentes, "pobres figuras que vivem só os maus bocados da existência". A matéria mostrava o encontro de tipos muito diferentes: "O buliçoso cotidiano das madames que vão à feira, os problemas e as chagas sociais dos que o habitam e nele vivem" (29/05/1968, p. 5).

Em 1967, eram grandes as expectativas quanto à possibilidade de Florianópolis vir a integrar as regiões metropolitanas do país, criadas por lei Federal. Contudo, a cidade não foi incluída entre as áreas prioritárias. A chamada de capa mais importante de O Estado no dia 19 de Dezembro daquele ano foi: "Florianópolis não será área metropolitana” (p. 1). Isso não diminuiu a retórica favorável às medidas administrativas que, segundo seus partidários, transformariam a cidade. Para o jornal, a Capital de Santa Catarina era "a cidade que se recusou a parar" e promoveu "uma política administrativa de superação", com a qual conjugou, "no presente e no futuro, o verbo do planejamento aliado à ação" (12/05/1968, p. 4). As obras de infraestrutura da década seguinte foram então projetadas, principalmente a construção de uma nova ponte entre a parte insular e a continental da cidade, pois a velha Hercílio Luz, construída no início do século XX, não mais dava vazão ao fluxo de trânsito: “a pobre ponte, já balzaquiana, vai suportando a duras penas enormes filas de veículos parados sobre si” (11/08/1968, Suplemento, p. 1)

A implementação de normas de gestão urbana estabelecidas pelo governo federal, que redundaram na elaboração do Plano de Desenvolvimento Integrado da Área Metropolitana, entre 1969 e 1971 (LOHN, 2011). Este documento seria uma das bases para o Plano Diretor finalmente aprovado em Junho de 1976, durante a gestão do prefeito Esperidião Amin. O objetivo era "a transformação de Florianópolis em um grande centro urbano" para "equilibrar a atração de São Paulo, de Curitiba e de Porto Alegre" (ESCRITÓRIO CATARINENSE DE DESENVOLVIMENTO INTEGRADO, 1971, p. 5-8). Como potenciais econômicos, a Capital apresentava a maior indústria de construção civil, a maior valorização imobiliária e condições para ser zona prioritária de investimentos turísticos. Obras públicas de grande impacto marcaram a fisionomia urbana de Florianópolis. Como grande beneficiário político do processo de mudanças, Amin incorporou à legislação municipal as diretrizes do planejamento urbano daquela década e palmilharia, a partir daí, uma 
carreira política destacada. O proprietário de $O$ Estado e ainda figura política mais influente na cidade, Aderbal Ramos da Silva, pontuou o surgimento da nova liderança: como "um ilhéu bem-humorado, enamorado pela cidade e preocupado com seu futuro" ficava "tranquilo de saber que agora ela está em boas mãos", pois o prefeito Amin tinha "bons planos" como "este boulevard [calçadão] que estão projetando para a Felipe Schmidt" e "vai mudar a fisionomia da cidade, para melhor" (14/05/1976, Suplemento Especial "Brazil, Capital Desterro”, p. 16). Era o próprio prefeito que se manifestava no mesmo ano, ao valer-se de narrativa apontada para a prospecção do futuro: "se não salvarmos agora o que é possível em termos de tentativa de racionalizar o crescimento de Florianópolis, nunca mais salvaremos a nossa cidade" (10/06/1976, p. 15).

Inicialmente, os governos do regime militar mantiveram mecanismos de intervenção no desenvolvimento das cidades centrados numa política habitacional retoricamente voltada para a solução das moradias precárias da população mais pobre. Contudo, aos poucos, o sistema financeiro montado voltou-se para as camadas médias, em busca de maior rentabilidade. Após 1973, a política urbana integrou-se a um conjunto de estratégias declaradamente voltadas para superar desequilíbrios regionais, através de ações conjuntas que preconizavam uma gestão do território nacional a partir de pólos urbanos (SCHMIDT; FARRET, 1986, p. 33). O desenvolvimento urbano recebeu um capítulo específico no II Plano Nacional de Desenvolvimento (PND). A resolução da dualidade entre grandes metrópoles e "a excessiva pulverização de pequenas cidades, sem um número adequado de cidades médias" que possibilitassem "equilíbrio ao conjunto", tais como Florianópolis, destinada "ao turismo e ao lazer" (BRASIL, 1975, p. 71-75).

A política urbana inseriu-se nos debates sobre a concentração de renda, num momento em que a oposição ao regime chamou a atenção para os efeitos do modelo econômico imposto. $\mathrm{O}$ espaço urbano apareceu então, na discussão oficial, "como um palco de problemas e as ações da política urbana deveriam corrigir os efeitos nocivos do modelo de crescimento econômico" (STEINBERGER; BRUNA, 2001, p. 46). Em 1976 foi anunciado o "Programa para Cidades de Porte Médio", com o objetivo de "reforçar pontos do 
espaço nacional potencialmente capazes de 'direcionar o processo de urbanização de maneira mais racional e estruturante, gerando opções aos fluxos migratórios e de capital"'. Entre as áreas previstas foram eleitas aquelas com "cidades de porte médio com potencial econômico ligado ao turismo e ao lazer” (POLÍTICA, 1976, p. 20-25).

O turismo, desde a década de 1960, ganhou as páginas de $O$ Estado com grande destaque. O proprietário do jornal era um dos maiores investidores em imóveis nas praias da cidade, principalmente no Norte da Ilha. Daí que a instalação de energia elétrica em vários balneários e a melhoria de estradas foram saudadas como a garantia de viabilidade econômica para a cidade e para os interesses privados. Apesar dos inúmeros problemas apontados, registravase o aumento do movimento nas praias nos finais de semana e os hotéis mostravam-se insuficientes para abrigar os turistas interessados em visitar a cidade. O ramo turístico vivia, na interpretação do jornal, "os seus grandes dias em nosso país, transformado em atividade econômica fundamental" (13/12/1967, p. 3). Uma Diretoria de Turismo e Comunicações da Municipalidade foi criada em 1967, pois a chamada "indústria sem chaminés" exigiria "um preparo de mercado e de uma organização que procure criar condições urbanísticas as mais aprimoradas" (12/03/1968, p. 3).

Os investimentos imobiliários e a retórica em favor do turismo trouxeram à tona a questão das grandes modificações no cenário urbano, particularmente a derrubada de edifícios e construções antigas para ceder lugar às novas obras. Isso ocorreu num momento em que, ainda durante os governos da ditadura militar, as cidades passaram a definir políticas de patrimônio "tendo como principal orientação o desenvolvimento do turismo" (LEITE, 2007, p. 34-60). Em 1974, uma construtora de Florianópolis lançou um anúncio cujo mote foi: "é uma pena, mas uma Capital não tem o direito de ser somente patrimônio histórico". A empresa afirmava "gostar muito da arquitetura do século XVII", mas apesar disso, ajudava "a construir a Capital do século XX”. (O Estado, 15/06/1974, Suplemento Especial, p. 11). Dias antes, $O$ Estado noticiou a criação do Serviço do Patrimônio Artístico e Natural do Município, "com a finalidade de proteger os prédios, monumentos, móveis, sítios e paisagens" de Florianópolis e "coibir a demolição de prédios antigos no centro 
da cidade" (01/05/1974, p. 12). A legislação municipal valia-se das políticas federais que atribuíram às cidades alguns mecanismos para a definição de bens culturais preservados. Contudo, ao incentivar o vínculo entre patrimônio e interesses turísticos, a lógica governamental resultou em favorecer o desenvolvimento de setores privados associados à exploração de negócios voltados ao lazer. Isso permitiu, a partir de uma definição de prioridades, que em nome do turismo e da exploração imobiliária, diversas modificações na estrutura urbana tenham simplesmente ignorado qualquer discussão patrimonial.

\section{Novos tempos}

Empreendimentos em regiões mais ou menos distantes do centro de Florianópolis abriram novas fronteiras de expansão da cidade. A mobilidade da maioria da população foi garantida precariamente pelo incremento de linhas de ônibus. Em 02 de Setembro de 1970, O Estado registrou a seguinte chamada: "Povo espera muito nas filas dos coletivos". As "filas quilométricas" estendiam-se nos terminais e as empresas concessionárias não ampliavam a frota ( $p$. 1). O que aumentou foi o número de automóveis em circulação e, com isso, alguns prosaicos problemas de trânsito foram noticiados. "Esta esquina já está precisando sinaleira" foi uma manchete que se referiu ao cruzamento entre duas importantes avenidas no centro, "palco permanente de acidentes de automóveis" (06/09/1970, p. 1).

Cidades-dormitório cresceram nas proximidades da capital, ao abrigar uma crescente população, constituída por trabalhadores da construção civil, que encontraram ocupação nas várias obras em andamento na capital. A Companhia de Habitação do Estado $(\mathrm{COHAB})$ anunciou estar "neutralizando os efeitos de um problema social", com a melhoria do "orçamento dos trabalhadores", desonerados das "despesas do aluguel", numa ação "associada aos objetivos do Banco Nacional de Habitação, que teve impulso extraordinário sob as diretrizes de regime, que a revolução de 1964 implantou no país" (03/03/1970, p. 3). Posteriormente, novos hábitos seriam registrados: em meados da década havia os que manifestavam o desejo de "abandonar o centro da cidade" para "residir definitivamente 
em bairros mais afastados, ou mesmo nos balneários e praias da Ilha". As ofertas pareciam atraentes: "quem conseguiu adquirir um lote antes da especulação, pode agora respirar tranqüilo, longe do barulho e da poluição visual e sonora existente no centro". O uso do automóvel viabilizava os novos hábitos: um morador de uma praia dizia-se contente porque "correndo um pouco, 'a uns $80 \mathrm{~km}$ por hora" conseguia "fazer em apenas 20 minutos" o percurso até o local de trabalho (21/03/1976, p. 15). Predominou uma forma de pensar o urbano que estava presa à lógica da individualização das classes médias, num processo próximo daquele descrito por Georg Simmel (2005, p. 577-591), quando acentuou a "mais alta impessoalidade" nas grandes cidades e a reserva diante do contato com outros.

Nas páginas de $O$ Estado há registros dessa demarcação de novas sociabilidades urbanas: em 1968, o jornal apontou que ainda continuavam a existir feiras livres na cidade, "com preços idênticos aos de armazéns e casas do gênero", mas sem "satisfazer os mínimos requisitos de higiene, armadas em barracas e caixotes, numa paisagem verdadeiramente medieval" (23/01/1968, p. 1). Anos depois, uma matéria antevia a "queda do balcão", ou seja, o fim de um tipo de relação comercial cara a cara entre clientes e proprietários, o que provocaria "a falência dos armazéns". As obras de desenvolvimento urbano e a massificação da cidade possibilitaram novos negócios, em especial a introdução dos supermercados que ameaçaram "a prosperidade das dinastias de proprietários das pequenas casas de comércio" (06/08/1972, p. 4).

Modos de vida, modas, jeitos e valores aproximaram-se daqueles oferecidos no mercado nacional de bens materiais e simbólicos. Segundo Renato Ortiz (1994, p. 113-138), ao aprofundar e remodelar o processo de industrialização e gestão econômica no Brasil, os responsáveis pelo regime autoritário implantado em 1964 promoveram a inserção do mercado nacional em mecanismos de internacionalização do capital. Para o autor, "em termos culturais essa reorientação econômica traz conseqüências imediatas, pois, paralelamente ao crescimento do parque industrial e do mercado interno de bens materiais, fortalece-se o parque industrial de produção de cultura e o mercado de bens culturais". Até o final da década, a cidade incorporou novos espaços através de grandes aterros e 
de uma nova ponte, que proporcionaria vazão a quase 15 mil veículos diariamente (O Estado, 10/03/1976, p. 1). Foram construídas vias de trânsito rápido, eixos prioritários de circulação. Ao chamar a atenção para a "especulação imobiliária" nas praias do município, $O$ Estado reproduziu a declaração de uma arquiteta que se referiu à área aterrada na Baía Sul como "um grande parque de estacionamento para absorver o crescente número de veículos particulares que cada dia mais invadem o miolo da cidade" (08/04/1976, p. 16).

O documento "Diretrizes para o uso do solo do aglomerado urbano de Florianópolis", apresentado em 1977, constatava que em poucos anos a cidade havia sido conduzida à "condição de importante pólo de comércio e de serviços" e que alguns investimentos em comunicações e transportes provocaram o "surgimento de um fluxo turístico de crescimento muito acima do previsível". Contudo, essas condições teriam também levado à "progressiva deterioração de alguns aspectos da qualidade da vida urbana de Florianópolis". Entre os fatores elencados estavam "a expulsão para a periferia das camadas de baixa renda", as longas distâncias para o transporte coletivo e a "diminuição da segurança" o que trazia "saudade da vida segura e tranqüila do florianopolitano que cultiva a cultura e o folclore, convive com a natureza e especialmente com o mar". Os "excepcionais níveis de crescimento da construção civil" e o "subemprego no setor de serviços" também alteravam a vida da população, que deixava tradicionais formas de ocupação, especialmente a pesca (FLORIANÓPOLIS, 1977, p. 7-8).

No ano em que a cidade completava 250 anos de fundação, as páginas do jornal apresentaram o novo cotidiano urbano: "só buracos, lixo e mau cheiro"; os congestionamentos "na hora do rush"; "Ônibus 10,57\% mais caro"; "custo de vida na Capital aumentou 6,92\%"; "os coletivos que ainda não atendem à coletividade"; "êxodo rural atinge todo o Estado"; "os problemas crescem em proporções geométricas"; "os favelados do aterro perguntam: para onde ir?". Estas são algumas manchetes recolhidas no primeiro semestre de 1976. O ritmo da narrativa procurou dar contornos e compartilhar uma determinada maneira de posicionar-se historicamente quanto ao processo que vivenciava. Num balanço histórico sobre as mudanças ocorridas no transporte público, o quadro 
O tempo da notícia: cidade, ditadura e redemocratização...

traçado por $O$ Estado não inspirava confiança no serviço: apesar do número de 137 veículos, os ônibus mantinham-se "superlotados na maior parte do dia" e constatava-se "ausência de novas linhas em áreas urbanizadas nos últimos anos" (25/03/1976, p. 16). A morosidade para a aprovação do Plano Diretor fazia com que a cidade continuasse "a crescer desordenadamente" e "a imagem dos 250 anos é vista pelos habitantes de uma ou duas décadas atrás com amargo ressaibo: o caos se consolida", porque "nascem prédios da noite para o dia, que ocupam desordenadamente os poucos espaços vazios da cidade" (26/03/1976, p. 16). Haveria, então, "o desafio de costurar o passado ao presente", dado que "em pouco mais de 10 anos Florianópolis mudou tanto sua fisionomia que as incisões dessa abrupta cirurgia plástica começam a exigir remédios urgentes" (30/03/1976, p. 1). Diferente do que se constatara até então, tornaram-se frequentes as referências à necessidade de preservação patrimonial, a visita a museus e a preocupação e a situação de igrejas e antigas construções que desapareciam rapidamente.

O período a partir do qual foi intensificado o processo que levaria à instauração do regime democrático no país foi vivido em Florianópolis, portanto, sob os ritmos urbanos de uma cidade que fora transformada nos anos da ditadura militar. A redemocratização envolveria vitórias eleitorais do partido da oposição consentida durante a ditadura, o MDB (Movimento Democrático Brasileiro), esgotamento do modelo econômica que havia ensejado os anos do "milagre" e a participação política das multidões urbanas, sob as mais diferentes formas. Em 1974, a crise parecia estar anunciada em $O$ Estado: "eis o produto que mais sobe na cidade: o aluguel". O sonho da moradia nos apartamentos do centro da cidade parecia distante no "eldorado dos imóveis", a cidade brasileira com "os aluguéis mais caros" (27/06/1974, p. 12). Em 1978, o jornal trazia a história de uma dona de casa moradora em um loteamento irregular na área continental que desafiara a polícia e resistira ao despejo: "sarrafo em punho, dona Vilma defende seu barraco" e "o direito que considera seu de permanecer morando onde está". Uma área estadual deveria ser desalojada e as famílias transferidas para um conjunto habitacional, mas a moradora reclamava dos barracos oferecidos pelo governo, com uma peça só e deficiência de saneamento (01/02/1978, 
p. 15). Na época, entre os poucos que pareciam considerar o custo de vida barato na cidade estavam os turistas argentinos. Em 1980 o jornal referiu-se a uma "invasão argentina": os turistas do país vizinho chegavam "cheios de dólares" e "compravam tudo". Fotos mostravam o centro tomado por "argentinos atravessando as ruas, carregados de pacotes” (15/01/1980, p. 16).

A compreensão da construção democrática no Brasil passa por levar em conta a constituição novas relações sociais, principalmente no cenário urbano. Para uma grande parcela da população as promessas de mobilidade social e consumo moderno foram parcialmente satisfeitas enquanto o desafio passou a ser o de construir lugares de vivência com o compartilhamento do trabalho entre familiares e suas redes de conhecidos num ambiente voraz e competitivo (SADER, 1988, p. 99-114). No momento em que o regime parecia estar no auge de sua capacidade de gerar legitimidade social, particularmente junto às camadas médias urbanas, este passou a sofrer reveses importantes. As eleições, que deveriam ser apenas momentos de reafirmação da força dos governos dos generais-presidentes, especialmente a partir de 1974, ganharam uma configuração inusitada. A política ressurgiu e ganhou as páginas de jornais e revistas. Aliado às dificuldades econômicas enfrentadas pelo governo a partir daí, com a desestabilização e o fim do período de crescimento acelerado, este processo somou-se às importantes mudanças socioculturais que marcaram a sociedade naqueles anos. A demanda por eleições e a valorização do voto introduziram elementos novos na cultura política brasileira, até então marcada pela desqualificação de mecanismos institucionais de participação popular e de imagens ressentidas forjadas na crença elitista sobre um suposto despreparo da população para o voto (BENEVIDES, 1994). Do mesmo modo, vieram a questionar os mecanismos autoritários de gestão do Estado impostos pela ditadura militar e que corresponderam ao poder de uma tecnocracia que se pretendeu modernizadora e legitimada por uma suposta eficácia administrativa.

As experiências das camadas populares, decorrentes de um cotidiano compartilhado por milhões de habitantes de cidades transformadas em ritmo veloz nos anos precedentes, passaram a 
O tempo da notícia: cidade, ditadura e redemocratização...

incorporar temas como cidadania e direitos civis, políticos e sociais. Movimentos de base, organizados a partir de diversas formas, seja nos sindicatos, nas igrejas, nas escolas ou mesmo em entidades partidárias, passaram a congregar esforços locais no sentido de praticar uma democratização no cotidiano. A emergência do chamado novo sindicalismo trouxe, à cena política, setores sociais até então sufocados. A grande imprensa, que durante grande parte do período apoiou e sustentou o regime militar, apareceu então como uma das vozes privilegiadas da democratização e construtora de uma memória histórica que consagrou a vitória de determinados agentes e setores políticos sociais. O noticiário jornalístico não aparece apenas como espectador, mas como interlocutor importante nas questões políticas que envolveram a chamada "distensão" e a posterior abertura "lenta, gradual e segura". As movimentações contra a censura prévia e as tentativas de alertar os leitores quanto à ação persecutória do Estado nas redações notabilizaram algumas publicações (AQUINO, 1999, p. 222-234). O fim da vigência do AI-5, em 1978, o posterior restabelecimento do pluripartidarismo e as eleições de 1982 são fundamentais para compreender as articulações que envolveram partidos, governantes, movimentos sociais e imprensa.

$\mathrm{Na}$ esteira dessa nova configuração política, a narrativa elaborada por $O$ Estado acerca das mudanças em curso aos poucos agrega elementos advindos das novas adesões sociais e do engajamento ao processo de transição para a democracia. O noticiário incorporou as negociações que levaram à abertura política. Importante destacar que, a esta altura, os textos produzidos no jornal são claramente influenciados para presença na redação de uma nova geração de jornalistas profissionais, o que seria acentuado com a criação do curso superior de jornalismo na UFSC. Em 1978, um artigo expressava as expectativas do jornal quanto ao cumprimento da "meta básica" do que chamava de "movimento revolucionário de 1964": "a condução do país à tão almejada normalidade democrática”. Após um período de "nuvem negra", haviam voltado as "condições que pudessem levar o Brasil ao encontro com a democracia" (01/02/1978, p. 4). Para Marcos Napolitano, "a 'linguagem dos direitos' parece ter norteado o discurso jornalístico do período, em que pese os diversos matizes ideológicos". O engajamento na "questão democrática", que 
circulava com ênfase no espaço público e nos textos jornalísticos desde a década anterior, contribuiu para que a imprensa obtivesse legitimidade social, pois "o que realmente estava em jogo era consolidação da hegemonia liberal no processo imediato de transição, o que foi plenamente atingido" (2002, p. 154-161).

Em 1979, em função do decreto que concedeu anistia aos que lutaram contra o regime, retornava a Santa Catarina, a primeira entre outros militantes que haviam buscado refúgio no exterior: "exilada catarinense retorna de Cuba disposta a fazer política". Derlei de Luca foi recebida por representantes da Comissão de Justiça e Paz e do Movimento Feminino pela Anistia: "começarei respirando o Brasil e participarei ativamente da política. $\mathrm{Na}$ oposição, é claro" (O Estado, 13/11/1979, p. 3). Dias depois, outro momento decisivo ocorreu na cidade: a chamada "novembrada". A visita do General João Figueiredo, empossado na presidência da República havia poucos meses, redundou num protesto contra a ditadura no centro de Florianópolis no dia 30 de Novembro. No dia da visita oficial, $O$ Estado anunciava que fora preparada uma grande recepção: "faixas, balões, bandinhas e 3 mil kg de carne para a festa". O governador do Estado, Jorge Bornhausen, procurava contribuir com os esforços políticos e publicitários que visavam melhorar a imagem do novo presidente e do regime. Mas, durante o cerimonial, uma grande manifestação popular saiu do controle das forças de segurança: o próprio general-presidente não escapou da fúria popular e "recebeu um empurrão" (MIGUEL, 1995, p. 41). A prisão de manifestantes levou a grandes mobilizações pela libertação dos que estavam sendo processados com base na Lei de Segurança Nacional tomaram as ruas. Nas fotos publicadas, é possível ler várias faixas com dizeres como "abaixo a ditadura", "chega de sofrer", "justiça" ou "abaixo a fome". Numa dessas manifestações, "mais de 7 mil pessoas" enfrentaram "mais de 700 soldados da Polícia Militar" em um ato público que "vinha sendo realizado pacificamente" em favor da "libertação dos cinco estudantes presos durante os tumultos da última sextafeira". Com a praça cercada pela polícia, um "grupo de 1.000 a 1.500 pessoas saíram em passeatas por todos os cantos do centro da cidade" (05/12/1979, p. 3.). O movimento estudantil voltou às ruas da cidade que, à sua maneira, compunha um dos cenários para as 
representações que evocavam as multidões através das quais eram elaborados os rituais públicos de cidadania e democracia.

A década de 1980 aprofundaria esta tomada das ruas e a campanha pelas eleições diretas para a presidência foi tanto um símbolo, como o auge de um processo mais amplo. As mobilizações atingiram um momento intenso com a campanha pelas eleições presidenciais diretas. Nas principais cidades brasileiras, sucessivos comícios com grande participação popular foram organizados para apoiar a frustrada tentativa de aprovação da constitucional apresentada pelo Deputado Federal Dante de Oliveira, do Partido do Movimento Democrático Brasileiro (PMDB). Em Florianópolis, O Estado afirmava acreditar nos "sentimentos liberais das camadas politicamente ativas de nossa população" e juntava-se aos que celebravam a democracia: "a elite política brasileira precisava convencer-se de que uma democracia se faz com idéias, com plataforma, com projetos definidos". O balanço histórico do regime mostrava que "experimentamos notável progresso material, ainda que não tenhamos logrado alcançar o desempenho político nos níveis desejáveis". Em 1984, foi visível a tentativa do jornal em adequar-se à nova conjuntura. "Povo na Praça XV pede as diretas" foi a manchete do dia 30 de março, referente ao comício do dia anterior, com a participação de Luís Inácio Lula da Silva, Ulysses Guimarães e Doutel de Andrade, entre outros. Entre as palavras de ordem: "o povo, na raça, já conquistou a praça". Um dos que se pronunciaram lembrou que naquele lugar ocorrera a "novembrada" e que "ali começamos a derrubar a ditadura".

A campanha pelas eleições diretas para a presidência da república tornou-se parte indissociável da memória histórica produzida desde então acerca do processo mais amplo de democratização do processo político brasileiro. As multidões extraordinárias de um país urbano, apresentadas nas páginas de jornais e revistas e a celebração da mobilização popular para exigir eleições, formam um quadro com elementos diversos que se constituíram naqueles anos. A campanha "concretizou uma aliança de homens públicos históricos com a nova geração de políticos que formava o PT [Partido dos Trabalhadores] e com diferentes integrantes de movimentos sociais" (DELGADO, 2007, p. 422). Mesmo órgãos de informação notoriamente ligados ao regime, como a TV Globo, quebraram o bloqueio da censura e, com isso, através das imagens televisivas, "na 
reta final da campanha, milhões de brasileiros puderam participar emocionalmente na luta por eleições diretas" (BERTONCELO, 2009 , p. 185). Nos meses seguintes, O Estado noticiou os avanços das negociações para a eleição de um presidente civil por um Colégio Eleitoral e contribuiu para garantir legitimidade para a transição. Uma pesquisa apontou o apoio popular à chapa da oposição: caso o eleitor de Florianópolis pudesse votar, daria " $46,7 \%$ dos votos a Tancredo" (02/09/1984, p. 1). O jornal defendia uma nova constituição (11/09/1984, p. 4) e noticiava os avanços da campanha de Tancredo Neves em todo o país: "multidão consagra a candidatura Tancredo", ao referir-se às 250 mil pessoas num comício em Goiânia (15/09/1984, p. 2).

A chamada Nova República teria seu início no ano seguinte, com importante base de apoio social. Em fins de 1984, O Estado anunciou outras importantes mudanças para o ano seguinte e que diziam respeito a Florianópolis. Mais um Plano Diretor passaria a ser discutido e a cidade começaria a preparar-se "para o ano 2000". O jornal também fazia um balanço da trajetória das duas últimas décadas e, para isso, procurou ouvir arquitetos e ex-prefeitos. Mais um "clima de mudanças" tomava conta da gestão urbana e apostava-se que "a conscientização e politização crescentes da população exercerão pressão no processo de crescimento da Capital". Durante "20 anos a população foi obrigada a aceitar todas as decisões passivamente". A partir de então, a sociedade passaria a opinar quanto ao "planejamento para a cidade em que mora". Para ex-prefeitos, cujos mandatos haviam sido exercidos nos anos da ditadura civil-militar, "o desenvolvimento de Florianópolis não acompanhou a íntegra das diretrizes traçadas no Plano Diretor", com "descaracterização do centro colonial da cidade". Mas os interlocutores desta memória histórica não deixavam de saudar que Florianópolis, apesar de ser uma das três menores capitais do país, alcançou naquelas décadas a condição de estar "entre as cinco de maior renda e padrão alto de vida". O futuro apontava para uma cidade na qual a "elitização" seria inevitável e que estaria "predestinada" a ser "estritamente turística” (30/12/1984, p. 8).

As eleições para a prefeitura de Florianópolis, após 25 anos, determinaram a vitória da oposição sobre a candidatura apoiada pelo então governador Esperidião Amin, artífice político do processo de 
modernização urbana da década anterior. No mesmo ano, algumas centenas de pessoas aglomeraram-se em frente à Catedral para assistir pela televisão, de maneira apática, segundo $O$ Estado, a eleição pelo Colégio Eleitoral de um Presidente Civil. Enquanto alguns turistas argentinos demonstravam curiosidade por saber o que ocorria, os momentos de emoção ficaram para o final do evento, quando foram executadas músicas como "O menestrel das Alagoas" e "Caminhando” (16/01/1985, p. 3). O PMDB ocupava o largo da Catedral, que se tornara um tradicional ponto de manifestação política desde a novembrada, mas o PT convocara seus militantes para manifestar repúdio ao Colégio Eleitoral, em outro ponto do centro, no calçadão da Rua Felipe Schmidt, com maior fluxo de pessoas. O espaço urbano convertia-se, ainda que ocasionalmente, em espaço público.

A narrativa encontrada em jornais como O Estado é parte constitutiva dos fenômenos sociais que marcam as memórias sociais e as narrativas históricas contemporâneas, ao assumir o papel de destaque na formação de referenciais compartilhados e que informaram em grande medida a compreensão histórica a qual aderiram amplas camadas da população brasileira. Tais representações sociais, que conformaram imagens e discursos, são imprescindíveis para a compreensão do papel dos meios de comunicação na construção de um tempo presente brasileiro. Os muitos cenários possíveis e as interpretações abertas compõem quadros narrativos que permitem, no dizer de Paul Ricoeur (1997, p. 360-372), “[...] lutar contra a tendência a se considerar o passado do ponto de vista do acabado, do imutável, do irretocável". Em Florianópolis, grande parte da população experimentou, sob condições diversas, os impactos socioculturais decorrentes da alteração de ritmos sociais e temporalidades. As narrativas que exprimiram tais experiências temporais lidaram com mudanças que desarticularam o que parecia estável, bem como marcaram de maneira indelével a atual experiência democrática brasileira. O intenso processo de urbanização, a formação de grandes contingentes de camadas médias urbanas e a estruturação de modernas estruturas de comunicação de massa tiveram efeitos políticos duradouros. 


\section{THE TIME OF THE NEWS: CITY, DICTATORSHIP AND REDEMOCRATIZATION IN THE PAGES OF O ESTADO (FLORIANOPOLIS, SC, 1964-1985)}

Abstract: This article discusses the relationship between the narratives produced in the newspaper $O$ Estado, published in Florianópolis (SC), the socio-cultural changes and the political processes related to the military dictatorship and the recent democratization of Brazil. The journalistic discourse shows itself as a social organizer, which includes the definition of what should be remembered or forgotten. Narratives elaborated in the newspaper have constituted supports for memories and for the construction of historical consciousness about the present time experienced during the transition between dictatorship and democracy.

Keywords: Newspaper. Narrative. Present time. Dictatorship. Democracy.

\section{Referências}

AQUINO, Maria Aparecida de. Censura, imprensa, Estado autoritário (1968-1978): o exercício cotidiano da dominação e da resistência: O Estado de São Paulo e Movimento. Bauru: Edusc, 1999.

BALDESSAR, Maria José; CHRISTOFOLETTI, Rogério (Orgs.). Jornalismo em perspectiva. Florianópolis: UFSC, 2005.

BENEVIDES, Maria Victoria de Mesquita. Cidadania e democracia. Lua Nova, São Paulo, n. 33, p. 5-16, 1994.

BERSTEIN, Serge. A cultura política. In: RIOUX, Jean-Pierre e SIRINELLI, Jean-François. (Orgs) Para uma História Cultural. Lisboa: Editorial Estampa, 1998. p. 352-353.

BERTONCELO, Edison Ricardo Emiliano. "Eu quero votar para presidente": uma análise sobre a campanha das diretas. Lua Nova, São Paulo, n. 76, p. 169-196, 2009.

BRASIL. Plano Nacional de Desenvolvimento, 2. São Paulo: Sugestões Literárias, 1975.

DECCA, Edgar Salvadori de. Memória e cidadania. In: PEREIRA, Maria Cristina (Org.). O direito à memória. Patrimônio histórico e cidadania. São Paulo: DPH/ SMC, 1992. p. 129-136.

DELGADO, Lucília de Almeida Neves. Diretas já: vozes das cidades. In: FERREIRA, Jorge; REIS, Daniel Aarão. As esquerdas no Brasil: Revolução e democracia (1964-...). Rio de Janeiro: Civilização Brasileira, 2007. p. 409-428. 
O tempo da notícia: cidade, ditadura e redemocratização...

ESCRITÓRIO CATARINENSE DE DESENVOLVIMENTO INTEGRADO. Plano de desenvolvimento da área metropolitana de Florianópolis. Florianópolis: [s.ed], 1971.

FERREIRA, Marieta de Moraes. História, tempo presente e História oral. Topói, Rio de Janeiro, v. 3, p. 314-332, jul./dez. 2002.

FICO, Carlos. Reinventando o otimismo: ditadura, propaganda e imaginário social no Brasil. Rio de Janeiro: Ed. FGV, 1997.

FLORIANÓPOLIS (SC). Estudos setoriais; diretrizes para o uso do solo no aglomerado urbano de Florianopolis. Florianópolis, SC: [s.n.], 1977.

HABERMAS, Jürgen. Mudança estrutural na esfera pública: investigações quanto a uma categoria da sociedade burguesa. Rio de Janeiro: Tempo Brasileiro, 1984.

IBGE. Estatísticas do Século XX. Rio de Janeiro: IBGE, 2003. 1 CD-ROM.

KOSELLECK, Reinhart. Futuro passado: contribuição à semântica dos tempos históricos. Rio de Janeiro: Contraponto; PUC-Rio, 2006.

LE GOFF, Jacques. História e memória. Campinas: Ed. Unicamp, 1994.

LEITE, Rogério Proença. Contra-usos da cidade: lugares e espaço público na experiência urbana contemporânea. Campinas: Ed. Unicamp; Aracaju: Ed. UFS, 2007.

LOHN, Reinaldo Lindolfo. Espaço urbano brasileiro: entre a ditadura e a democracia - o caso de Florianópolis, SC (1964-1990). Estudos Históricos. Rio de Janeiro, v. 24, n. 47, p. 162-181, 2011.

MIGUEL, Luís Felipe. Revolta em Florianópolis: a Novembrada de 1979. Florianópolis: Editora Insular, 1995.

NAPOLITANO, Marcos. Cultura e poder no Brasil contemporâneo. Curitiba: Juruá, 2002.

O ESTADO, Florianópolis, 1964-1985. Diário.

ORTIZ, Renato. A moderna tradição brasileira: cultura brasileira e indústria cultural. São Paulo: Brasiliense, 1994.

PEREIRA, Moacir. Imprensa e poder: a comunicação em Santa Catarina. Florianópolis: Lunardelli; FCC, 1992.

PEREIRA, Nereu do Vale. Desenvolvimento e modernização: um estudo de modernização em Florianópolis. Florianópolis: Lunardelli, s/d.

POLÍTICA urbana: programa para cidades de porte médio. P\&D: Planejamento e Desenvolvimento. Brasília, Coordenadoria de Comunicação Social, v. 3, n. 36, p. 20-25, mai. 1976. 


\section{Reinaldo Lindolfo Lohn}

PRADO, Luiz C. Delorme; EARP, Fábio Sá. O “milagre” brasileiro: crescimento acelerado, integração nacional e concentração de renda. In: FERREIRA, Jorge; DELGADO, Lucília de A. Neves (Orgs.). O Brasil republicano, 4: o tempo da ditadura. Regime militar e movimentos sociais em fins do século XX. Rio de Janeiro: Civilização Brasileira: 2003. p. 207-242

RIBEIRO, Ana Paula Goulart. Modernização e concentração: a imprensa carioca nos anos 1950-1970. In: NEVES, Lucia Maria Bastos; MOREL, Marco; FERREIRA, Tânia Maria Bessone (Orgs.). História e imprensa: representações culturais e práticas de poder. Rio de Janeiro: DP\&A; Faperj, 2006. p. 426-435.

; FERREIRA, Lúcia Maria Alves. (Orgs.) Mídia e memória. A produção de sentidos nos meios de comunicação. Rio de Janeiro: Mauad, 2007.

RICOEUR, Paul. Tempo e narrativa. Tomo III. Campinas: Papirus, 1997.

RÜSEN, Jörn. Rãão Histórica: teoria da história: fundamentos da ciência histórica. Brasília: UNB, 2001.

SADER, Eder. Quando novos personagens entraram em cena: experiências e lutas dos trabalhadores da Grande São Paulo (1970-1980). Rio de Janeiro: Paz e Terra, 1988.

SARLO, Beatriz. Tempo passado: cultura da memória e guinada subjetiva. São Paulo: Cia das Letras; Belo Horizonte: UFMG, 2007.

SCHMIDT, Benício; FARRET, Ricardo. A questão urbana. Rio Janeiro: Jorge Zahar, 1986.

SIMMEL, Georg. As grandes cidades e a vida do espírito (1903). Mana, Rio de Janeiro, v. 11, n. 2, p. 577-591, 2005.

STEINBERGER, Marília; BRUNA, Gilda Collet. Cidades médias: elos do urbano-regional e do público-privado. In: ANDRADE, Thompson Almeida; SERRA, Rodrigo Valente (Orgs.). Cidades médias brasileiras. Rio de Janeiro: IPEA, 2001. p. 35-77.

Recebido em 12/07/2012

Aprovado em: 10/09/2012 